\title{
EFFECT OF SOME ORGANIC ACIDS AND ORGANIC SALT BLENDS ON GROWTH PERFORMANCE AND FEED UTILIZATION OF NILE TILAPIA, (OREOCHROMIS NILOTICUS)
}

\author{
H.M. Agouz'; M.A. Soltan ${ }^{2}$ and Rasha N. Meshrf ${ }^{2}$ \\ ${ }^{1}$ Central Laboratory for Aquaculture Research, Abbassa, Abou-Hammad, Sharkia, Egypt. \\ ${ }^{2}$ Faculty of Agric., Banha Univ., Egypt.
}

\section{SUMMARY}

$\mathrm{T}$ The present study was carried out to study the effect of supplementation of Nile tilapia (Oreochromis niloticus) diets by increasing levels $(0.5,1.0$ and $1.5 \%)$ of two organic acids (malic acid + oxalic acid, 1:1) blend and two organic acid salts (calcium lactate + sodium acetate, 1:1) blend. Therefore 7 diets were formulated (three diets for each blend and the control diet). Growth performance, feed utilization, some hematological parameters and proximate analysis of fish were determined after 90 days. Results could be summarized as follows: Supplementation of the basal diet by each of malic+oxalic acids blend or $\mathrm{Na}$-acetate+Ca-lactate blend significantly improved the final body weight (BW), body length (BL), weight gain (WG) and specific growth rate (SGR) of Nile tilapia compared with the control diet. Fish fed the diet supplemented by $1 \%$ malic+oxalic acids blend showed the highest BW, BL, WG and SGR compared with control and the other treated fish groups and the same trend was also observed for feed intake, feed conversion ratio (FCR) and protein efficiency ratio (PER). Fish fed the diet D4 (supplemented by $1.5 \%$ malic+ oxalic) showed the highest serum protein content while control group showed the highest level of total lipids compared with the other treatments. Fish group fed D5 (0.5\% of 1:1 Na-acetate + Ca-lactate blend) showed the highest protein and ash content and the lowest lipid content of the whole fish body, whereas control group showed the lowest protein and the highest fat content.

Keywords: Organic acids, organic salts, growth performance and Nile tilapia.

\section{INTRODUCTION}

Organic acids are an example of a group of additives which can play an important role in future in aquaculture diets. A number of studies, in cold-water species (Gislason et al., 1994 and 1996) and tropical species (Ramli et al., 2005 and Petkam et al., 2008), indicated a broad range of organic acids, their salts or mixtures can improve growth, feed utilization and disease resistance in fish.

Organic acids in animal feed were initially used in piglets to compliment their limited capacity to maintain a low gastric $\mathrm{pH}$, which linked to problems with digestion (Easter, 1988). Antibiotic inhibit all microbial growth, whereas acidifiers are more selective in their activity (Cromwell, 1990). They can reduce harmful micro-organisms and promote beneficial microflora colonization of the gastrointestinal tract (Mathew et al., 1991).

As reviewed by Baruah et al., (2008), the addition of organic acids in fish feeds may have many advantages; it may reduce the unwanted pathogenic microbial load in feed and the gut of fish; reduce toxic microbial metabolites by reducing the pathogenic microbes; enhance nutrient absorption due to proliferation of mucosal epithelium of the intestine; reduce the discharge of phosphorus in water thereby preventing aquatic pollution; reduce the risk of antibiotic residue in fish and prawns in those regions where antibiotics are used. Mineral absorption may also be enhanced due to more solubilization of $\mathrm{Ca}, \mathrm{P}$ and $\mathrm{Mg}$ etc from animal protein sources, especially in stomach-less fishes.

Some organic acids especially citric, metacetonic and acetic, are also added to pellets for storage effects and/or the improvement of feed utilization (Kumar et al., 1997 and Sugiura et al., 1998).

Generally, the present study was carried out to investigated the effect of some organic acids (1:1 malic+oxalic acids blend) and organic acid salts (1:1 Na-acetate+Ca-lactate blend) at increased levels $(0$, $0.5,1.0$ or $1.5 \%$ of these blends) on the growth performance, feed utilization, proximate analysis and some physiological aspects of Oreochromis niloticus. 


\section{Agouz et al}

\section{MATERIALS AND METHODS}

The present study was carried out at the Laboratory of Fish Nutrition Faculty of Agriculture Benha University. Fish were obtained from Abbassa hatchery. After acclimatization, the experimental fish were distributed randomly into the experimental aquaria. Fourteen rectangular aquaria $100 \times 40 \times 50 \mathrm{~cm}$ were used in the study and the aquaria were supplied with aerated and dechlorinated tap water. Each aquarium was filled with 160 liter and stocked with 15 fish $(7.05 \pm 0.02 \mathrm{~g})$. One water filter, heater and air pump were used for each aquarium.

At stocking, body weight and body length of fingerlings for each aquarium were individually recorded. Water filters were cleaned and about $10 \%$ of the water was daily renewed. Dissolved oxygen was maintained at 4- $6 \mathrm{mgll}$ by continuous aeration and water temperature at $28^{\circ} \mathrm{C}$.

Diets were prepared to confirm the control diet, organic acids (malic acid and oxalic acid blend 1:1) and organic salts (calcium lactate and sodium acetate blend 1:1) were incorporated in three different doses, 0.5, 1.0 and $1.5 \%$ (for each blend) therefore seven experimental diets were formulated (three diets for each blend and control diet). Diets were prepared by thoroughly mixing the ingredients (table 1). Water was added to the ingredients of each diet for mixing these ingredients and then dried. After drying, the diets were broken up and sieved into the convenient pellet size.

Fish were given the diets 6 day/week at daily rate of $3 \%$ (twice daily at 9.00 am and $3.00 \mathrm{pm}$ ). Every two weeks, total fish for each aquarium was weighted and the amount of feed was adjusted according to the changes in body weight through the experimental period. Growth performance parameters were measured by using the following equations:

Weight gain $(\mathrm{WG})=$ final weight $(\mathrm{g})-$ initial weight $(\mathrm{g})$.

Specific growth rate $(\mathrm{SGR})=\mathrm{LnW} 2-\mathrm{LnW} 1 / \mathrm{t}$ (days), Where, Ln=the natural log; $\mathrm{W}_{1}=$ first fish weight, $\mathrm{W}_{2}=$ the following fish weight in grams and $\mathrm{t}=$ period in days.

Feed conversion ratio $(\mathrm{FCR})=$ Feed intake $(\mathrm{g}) /$ weight gain $(\mathrm{g})$.

Protein efficiency ratio $($ PER $)=$ Weight gain $(\mathrm{g}) /$ protein ingested $(\mathrm{g})$.

Blood samples were collected from caudal vein of non-anesthetized fish using plastic syringe containing heparin. Hemoglobin $(\mathrm{g} / \mathrm{dl})$ was estimated spectrophotometrically by hemoglobin kits and the Haematocrit (Ht) was determined according to Stoskopf (1993) and reported as percentage packed cell volume (\% PCV).

Another blood samples were collected in clean Eppendrof tubes. The plasma was obtained by centrifugation at 3,000 rpm for $15 \mathrm{~min}$, and plasma was stored at $-20^{\circ} \mathrm{C}$ for further assays. Total lipids and total protein contents of plasma were determined colorimetrically according to Joseph et al. (1972) and Henry (1964), respectively. Alanine aminotransferase (ALT) and Aspartate aminotransferase (AST) spectrophotametrically determined according to Reitman and Frankel (1957).

At the end of the experiment, two fish were randomly sampled from each aquarium and subjected to the chemical analysis of whole fish body according to the methods described in AOAC (1990): dry matter after drying in an oven at $105^{\circ} \mathrm{C}$ until constant weight; ash content by incineration in a muffle furnace at $600^{\circ} \mathrm{C}$ for $12 \mathrm{hrs}$; crude protein $(\mathrm{N} \times 6.25)$ by the kjeldhal method after acid digestion; and ether extract by petroleum ether $\left(60-80^{\circ} \mathrm{C}\right)$ extraction.

Statistical analysis of the obtained data was analyzed according to SAS (1996). Differences between means were tested for significance according to Duncan's multiple rang test (Duncan, 1955).

\section{RESULTS AND DISCUSSION}

\section{Growth performance:}

At experiment termination results showed that, supplementation of the basal diet by each of malic+oxalic acids blend or Na-acetate+Ca-lactate blend significantly improved the final BW, BL, WG and SGR of Nile tilapia compared with the control group (Table 2). Also, fish fed the diet supplemented by $1 \%$ malic+oxalic acids blend showed the highest BW $(25.45 \mathrm{~g})$; the longest BL $(12.20 \mathrm{~cm})$; the best WG (18.45 g) and SGR (1.40\%) while control group showed the lowest BW (21.85 g); shortest BL (9.95 $\mathrm{cm})$, the worst WG $(14.85 \mathrm{~g})$ and SGR $(1.33 \%)$. Differences among the different treatments in BW, BL, WG and SGR were significant $(\mathrm{P}<0.05)$.

The obtained results for BW were parallel to those obtained for BL, WG and SGR (table 2) indicating that the acidification of $O$. niloticus diets significantly improved growth performance. 
Ramli et al. (2005) concluded that K-diformate $(0.2,0.3$ or $0.5 \%)$ significantly $(\mathrm{P}<0.05)$ improved BW and WG of $O$. niloticus. Petkam et al., (2008) found that, $1.5 \%$ of Ca-formate, Ca-propionate, Calactate, and citric acid blend resulted in a numerical increase in WG of $11 \%$ versus negative control. In recent study, Mogheth (2012) showed that supplementation of the basal diet by $1 \%$ Ca-lactate significantly $(\mathrm{P}<0.001)$ improved BW, BL, WG and SGR of Nile tilapia, O. niloticus. In another study, Eid (2012) reported that, the organic acid blend ( $0.3 \%$ acitic acid +0.3 formic acid and 0.3 benzoic acid) and organic acid salts blends $(0.3 \%$ sodium benzoate $+0.3 \%$ potassium sorbate) significantly enhanced WG and SGR of $O$. niloticus compared to controld group.

For other fish species, de Wet (2005) described that, after 3 months final BW and SGR of rainbow trout fingerlings, Oncorhynchus mykiss were significantly improved with increasing acid blend (formic acid and its salts+sorbic acid) inclusion (from 0.5 to 1.0 or $1.5 \%$ ) versus control $(\mathrm{P}<0.05)$.

Ring $\varnothing$, (1991) and Gislason et al., (1996) found that Arctic charr, Salvelinus alpinus fed the diets supplemented by each of $1 \%$ Na-lactate or $1 \%$ Na-propionate significantly $(\mathrm{P}<0.05)$ improved SGR. In another study Ring $\varnothing$ et al., (1994) found that supplementation of Arctic charr diets by $1 \%$ Na-acetate significantly $(\mathrm{P}<0.05)$ improved SGR compared with control fish group. For sea bream (Pagrus major), Hossain et al., (2007) used $1 \%$ each of citric acid, malic acid and lactic acid in three different dietary groups. They showed a significant improvement for WG in the citric acid group versus negative control, but malic or lactic acid did not improve SGR.

\section{Feed intake and feed utilization:}

During the entire experimental period (90 days), supplementation of tilapia diets by the two blends of organic acids and organic salts significantly $(\mathrm{P}<0.05)$ increased feed intake (table 3$)$. Ramli et al., (2005) found that from day 1 to day $85, \mathrm{~K}$ - diformate significantly $(\mathrm{P}<0.01)$ improved feed intake and the improvement was greater for 0.2 and $0.5 \% \mathrm{~K}$-formate addition. Mogheth (2012) indicated that, supplementation of tilapia diets by Ca-propionate and Ca-lactate significantly $(\mathrm{P}<0.05)$ increased feed intake.

Citric and lactic acids have been reported to be effective in stimulating or enhancing feeding behavior when applied individually or together with other extractive compounds in Tilapia zilli (Adams et al., 1988). If the stimulatory effect on fish is confirmed, it could improve fish feed quality regarding both storage and feeding stimulation.

Supplementation of the basal diets by blends of malic+oxalic acid or Na-acetate+Ca-lactate significantly $(\mathrm{P}<0.05)$ improved FCR of $O$. niloticus and D3 (the diet supplemented with $1 \%$ of malic+oxalic blend) showed the best FCR (table 3). Mogheth (2012) showed that during 90 day experimental period FCR for $O$. niloticus fed the control diet showed the highest (worst) FCR compared to the other experimental diets supplemented with the different doses $(0.5,1.0$ or $1.5 \%)$ of Ca-propionate and Ca-lactate.

For other fish species, de Wet (2005), noticed an improvement in FCR for rainbow trout fingerlings, Oncorhynchus mykiss fed a diet supplemented by $1.5 \%$ blend of formic acid and its salts plus sorbic acid. Ringø (1992) found that, supplementation of Arctic charr, Salvelinus alpinus diets by each of $1 \% \mathrm{Na}$ formate or $1 \%$ Na-acetate improved FCR. In another study for the same fish specie, Ring $\varnothing$ et al., (1994) found that supplementation of fish diets by $1 \%$ Na-lactate improved FCR.

Fish group fed D3 (1.5\% malic+oxalic acids blend) showed the highest protein efficency ratio, PER (table 3) which was significantly higher than that obtained for the other treated fish groups indicating the superiority of supplementation of this organic acid blend with this dose (1\%). Similar results were also obtained by Ramli et al., (2005). The authors found that, from day 1 to day 85, PER of Nile tilapia $O$. niloticus was significantly $(\mathrm{P}<0.01)$ improved due to the addition of 0.2 and $0.5 \%$ formate. Mogheth (2012) indicated that from 1 day to 12 week the basal diet supplemented with $1.5 \%$ Ca-lactate showed the highest PER (1.93) which was significantly higher than obtained for fish fed the control (1.65) diet.

Generally the obtained results of the present study indicated that, supplementation of Nile tilapia diets by organic salts (malic+oxalic acids blend and $\mathrm{Na}$-acetate+Ca-lactate blend) significantly improved $\mathrm{BW}$, BL, WG and SGR, feed intake, FCR and PER.

The improvement in growth performance and feed utilization due to acidification may be due to increasing the absorbance and availability of different minerals and increasing secretion of some enzymes such as proteases. Vielma et al., (1999) reported that dietary acidification by citric acid significantly increased whole body iron in fish. Sugiura, et al., (1998) also observed an increase in the apparent availability of $\mathrm{Ca}, \mathrm{P}, \mathrm{Mg}, \mathrm{Mn}$ and $\mathrm{Fe}$ in rainbow trout fed fish meal-based diets supplemented with citric acid.

Li et al., (2009) indicated that, supplementation of the diets of hybrid tilapia (O. niloticus $\times O$. aureus) by citric acid $\left(10 \mathrm{~g} \mathrm{~kg}^{-1}\right)$ increased the activities of protease in stomach by $29.6 \%$, but reduced the activities of protease in the intestine by $35.1 \%$. Citric acid increased the activities of amylase in the hepatopancreas 
and intestine by $30.7 \%$ and $29.4 \%$ and they concluded that, it is possible that trace elements released by citric acid may have contributed to the increase on protease activity.

\section{Some blood parameters and liver fucntions:}

The average values of hemoglobin $(\mathrm{Hb})$ ranged between 7.95 to $8.80 \mathrm{u} / \mathrm{ml}$ and values of hematocrit (Ht) ranged between 24.00 and $9.50(\mathrm{PCV} \%)$ and the differences between $\mathrm{Hb}$ or $\mathrm{Ht}$ values were significant (Table 4).

Total protein and total lipids ranged between 4.85 to 6.35 and 98.00 to $117.5 \mathrm{~g} / \mathrm{dl}$, respectively. Fish fed the diet D4 (supplemented by $1.5 \%$ malic+ oxalic) showed the highest total protein content and the control group showed the lowest total protein content. Total lipids in control group showed the highest value $(117.5 \mathrm{~g} / \mathrm{dl})$ compared with the other treatments. In the same trend values of ALT and AST ranged between 10.50 to 13.00 $\mathrm{u} / \mathrm{ml}$ with insignificant differences between these means for ALT and between 13.00 to $16.00 \mathrm{u} / \mathrm{ml}$ with significant differences for AST (Table 4).

Hematology is an important factor that could be considered for the fish diet quality assessment. Hari et al., (2004) reported that ichthohematology would be useful for the assessment of suitability of diets and feed mixtures, evaluation of fish conditions, determination of toxic effect of substances, as well as the diagnosis of disease. Avnimelech et al., (1994) reported that one of the most common blood variables consistently influenced by diet is the $\mathrm{Hb}$ and $\mathrm{Ht}$ levels.

Serum total protein is used as a basic index for health status of fish (Mulcahy, 1971), which plays a significant role in the immune response. The estimations of serum enzyme activities of ALT and AST are taken as an indication of the amount of liver damage as the elevated serum enzyme levels might be related to the degree of liver injury. Liver disease causes an increase in some serum enzymes by locking their elimination into the blood (Barraze et al 1991).

\section{Proximate analysis of whole fish:}

Chemical analysis at the end of a feeding trial is frequently used to determine the influence of feed on fish composition. According to Hepher (1990), endogenous factors (size, sex and stage of life cycle) and exogenous factors (diet composition, feeding frequency, temperature etc.) affect the body composition of fish. It should be noted that within endogenous factors, feed composition is only factor, which could have influenced the chemical composition of fish, as other endogenous factors were maintained uniform during the study.

Dry matter in the whole fish body ranged between 26.30 and $27.15 \%$. Control fish group showed the significant $(\mathrm{P}<0.05)$ highest dry matter content while fish fed the diet $\mathrm{D} 2$ (supplemented by $0.5 \%$ of $1: 1$ malic+oxalic blend) showed the lowest dry matter content (Table 4). Protein content of the whole fish ranged from $68.00 \%$ for control group to $69.60 \%$ for fish fed the diet D5 (supplemented by $0.5 \%$ of $1: 1$ $\mathrm{Na}$-acetate+Ca-lactate blend) and the opposite trend was observed for fat content.

Ash content ranged between $13.7 \%$ (D6) to $15.10 \%$ (D5). Incorporation of organic acids or their salts in $O$. niloticus diets significantly affected proximate analysis of the treated fish. Vielma et al., (1999) found that acidification of rainbow trout diets by citric acid increased whole-body ash content. Baruah et al., (2007) indicated that, whole-body ash content of rohu, Labeo rohita juveniles was not significantly $(\mathrm{P}>0.05)$ affected by citric acid. Similar results were also reported by Van Weerd et al., (1999) in Clarias gariepinus and Vielma et al., (1998) in rainbow trout.

Proximate analysis of the present study showed that fish group fed D5 (the basal diet supplemented by $0.5 \%$ of $1: 1 \mathrm{Na}$-acetate+Ca-lactate blend) showed the highest protein and ash content and the lowest lipid content of the whole fish body while control group showed the lowest protein and the highest fat content. Therefore a negative relationship was observed between protein and fat content of the whole fish body and these results are in agreement with those obtained by Goda (2002) and Mogheth (2012) who found a negative correlation between protein and fat content of Nile tilapia. On the other hand, El-Saidy et al., (1999) found that there was a positive correlation between crude protein and fat content of $O$. niloticus.

\section{REFERENCES}

Adams, M.A.; P. B.Johnsen and H. Q. Zhou (1988). Chemical enhancement of feeding for the herbivorous fish Tilapia zillii. Aquaculture, 72:95-107.

AOAC (1990): Official methods of analysis, $15^{\text {th }}$ ed, Published by the Association of Official Analytical Chemists, North Nineteenth St. Auntie 210, Arlength, Virginia 2220/ USA,1298.

Avnimelech, Y.; M. Kochva and S. Diab (1994). Development of controlled intensive aquaculture systems with a limited water exchange and adjusted carbon to nitrogen ratio. Bamidgeh, 46:119-131. 
Barraze, M.I.; C.E. Coppock; K.N. Brooks; D.L. Wilks; R.G. Saunders and J.R. Latimer (1991). Iron sulfate and feed pelleting to detoxify free gossypol in cotton seed diets for dairy cattle. J Dairy Sci., 74:3457-3467.

Baruah, K.; P. Norouzitallab; D. Debnath; A.K. Pal and N.P. Sahu (2008). Organic acids as non-antibiotic nutraceuticals in fish and prawn feed. Aquaculture Health International. March 2008.

Baruah, K.; A.K. Pal; N.P. Sahu; D. Debnath; S. Yengkokpam and S.C. Mukherjee (2007). Interactions of microbial phytase, citric acid and crude protein level on mineral utilisation by rohu, Labeo rohita juveniles. Journal of World Aquaculture Society, 38:238-249.

Cromwell, G.L. (1990). Antimicrobial agents. In: Swine Nutrition. Edited by E. R. Miller, D. E. Uiirey and A. J. Lewis. Butterworth-Heiemann. Boston, MA, USA pp. 297-313.

De Wet, L. (2005). Can organic acids effectively replace antibiotic growth promotants in diets for rainbow trout Oncorhynchus mykiss raised under sub-optimal water temperatures? Abstract CD-Rom, World Aquaculture Society; 9-13 May 2005; Bali, Indonesia; 2005.

Duncan, M.B. (1955). Multiple ranges and multiple F-tests. Biometrics, 11:1-42.

Easter, R.A. (1988). Acidification of diets for pigs. In: Recent Advances in Animal Nutrition. Edited by W. Haresign and D.J.A. Cole. Butterworth, London, UK. PP. 61-72.

Eid, A. (2012). Effect of organic acids and organic acid salts as growth promoters for fingerlings Nile tilapia. Egyptian J. Nutrition and Feeds, 15(1):414 (Abstract).

El-Saidy, D.M.; M.M. Gaber and F.I. Magouz (1999). Effect of dietary energy level on growth, feed conversion, body composition, digestibility coefficients and energy budget of Nile tilapia (Oreochromis niloticus L.). Egypt. J. Aquat. Biol. \& Fish., 3(3):159-178.

Gislason, G.; R.E. Olsen and E. Ring $\varnothing$ (1994). Lack of growth-stimulating effect of lactate on Atlantic salmon, Salmo salar L. Aquaculture and Fisheries Management, 25:861-862.

Gislason, G.; R.E. Olsen and E. Ring (1996). Comparative effects of dietary Na-lactate on Arctic charr, Salvelinus alpinus L., and Atlantic salmon, Salmo salar L. Aquaculture Research, 27:429-435.

Goda, A.M. (2002). The influences of $\mathrm{n} 6 / \mathrm{n} 3$ dietary fatty acid ratio on growth performance and body fatty acid composition of Nile tilapia (Oreochromis niloticus). Vet. Med. J. Giza, 50(1):33-45.

Hari, B.; B.M. Kurup; J.T. Varghese; J.W. Schrama and M.C.J. Verdegem (2004). Effects of carbohydrate addition on production in extensive shrimp culture systems. Aquaculture. 241:179-194.

Henry, R.J. (1964). Colorimetric determination of total protein. In: Clinical Chemistry. Harper and Row Publ., New York, USA, p 181.

Hepher, B. (1990). Ingestion, digestion and absorption of food. In: B. Hepher, (Ed.). Nutrition of Pond Fishes. Academic Press, Cambridge, pp, 16-63.

Hossain, M.A.; A. Pandey and S. Satoh (2007). Effects of organic acids on growth and phosphorus utilization in red sea bream Paugrs major. Fisheries Science, 73:1309-17.

Joseph, A.; M. Knight; S. Anderson; M. James and H. Rawie (1972). Chemical basis of the sulfophosphovanillin reaction for estimating total serum lipid. Clinical Chemistry, 18:198-201.

Kumar, D.; H. Kaller; N. Bhaskar; M.H. Bhandary; M.J. Antony; C.V. Raju and V.M. Biradar (1997). Lipid oxidation and subsequent browning in salted-dried mackerel (Rastrelliger kanagurta Cuvier). Ind. J. Fish., 44:377-385.

Li, J.S.; J.L. Li and T.T. Wu (2009). Effects of non-starch polysaccharides enzyme, phytase and citric acid on activities of endogenous digestive enzymes of tilapia (Oreochromis niloticus $\times$ Oreochromis aureus). Aquaculture Nutrition, 15:415-420.

Mathew, A.G.; A.L. Sutton; A.B. Scheidt; D.M. Forsyth; J.A. Patterson and D.T. Kelly (1991). Effects of a propionic acid containing feed additive on performance and intestinal microbial fermentation of the weanling pigs. In: Proceedings Sixth International Symposium on the Digestive Physiology in Pigs. PUDOC. Wageningen, the Netherlands. Pp. 464-469.

Mogheth, N.M. (2012). Effect of some feed additives on growth of Nile tilapia. M.Sc. Thesis, Fac. Agric., Moshtohor, Benha University, Egypt.

Mulcahy, M.F. (1971). Serum protein changes associated with ulcerative dermal necrosis (UDN) in the trout Salmo trutta L. J. Fish Biol., 3:199-201.

NRC (1993). National Research Council. Nutrient requirements of fish. National Academy Press, Washington D.C.

Petkam, R.; C. Lückstädt; P. Nittayachit; S. Sadao and P. Encarnacao (2008). Evaluation of a dietary organic acid blend on tilapia Oreochromis niloticus growth performance. Abstract CD-Rom, World Aquaculture Society, 19-23 May 2008, Busan, Korea.

Ramli, N.; U. Heindl and S. Sunanto (2005). Effect of potassium-diformate on growth performance of tilapia challenged with Vibrio anguillarum. Abstract CD-ROM World Aquaculture Society, 9-13 May 2005; Bali, Indonesia. 
Reitman, S. and S. Frankel (1957). A colorimetric method for determination of serum glutamic oxaloacetic and glutamic pyruvic transaminases. Am. J. Clin. Path; 28:56.

Ring $\varnothing$, E. (1991). Effects of dietary lactate and propionate on growth and digesta in Arctic charr, Salvelinus alpinus (L.). Aquaculture, 96:321-33.

Ring $\varnothing$, E. (1992). Effects of dietary formate and acetate on growth and lipid digestibility in Arctic charr, Salvelinus alpinus (L.). Fiskeridirektoratets Skrifter. Serie Ernaering, 5:17-24.

Ring $\varnothing$, E., Olsen, R. E. and Castell, J. D. (1994). Effect of dietary lactate on growth and chemical composition of Arctic charr Salvelinus alpinus. Journal of the World Aquaculture Society, 25:483-6.

SAS (1996). SAS Procedure Guide version 6.12 Ed. SAS Institute Inc., Cary, NC, USA.

Stoskopf, M.K. (1993). Shark. Pharmacology and toxicology. Fish medicine, W.B. Saunders Company, Mexico 809-839.

Sugiura, S.H.; F.M. Dong and R.W. Hardy (1998). Effects of dietary supplements on the availability of minerals in fish meal; preliminary observations. Aquaculture, 160:283-303.

Van Weerd, J.H.; K.H. Khalaf; F.J. Aartsen and P.A. Tijssen (1999). Balance trials with African catfish, Clarias gariepinus fed phytase-treated soybean meal-based diets. Aquaculture Nutrition, 5:135-142.

Vielma, J.; S.P. Lall; J. Koskela; F.J. Schner and P. Mattila (1998). Effects of dietary phytase and cholecalciferol on phosphorus bioavailability in rainbow trout, Oncorhynchus mykiss. Aquaculture, 163:309-323.

Vielma, J.; K. Ruohonen and S.P. Lall (1999). Supplemental citric acid and particle size of fish bone-meal influence the availability of minerals in rainbow trout, Oncorhynchus mykiss (Walbaum). Aquaculture Nutrition, 5:65-71.

Table (1). Composition and chemical analysis of the experimental diets.

\begin{tabular}{|c|c|c|c|c|c|c|c|}
\hline \multirow[t]{2}{*}{ Feed ingredients } & \multicolumn{7}{|c|}{ Experimental diets } \\
\hline & Diet 1 & Diet 2 & Diet 3 & Diet 4 & Diet 5 & Diet 6 & Diet 7 \\
\hline Fish meal $(65 \%)$ & 16 & 16 & 16 & 16 & 16 & 16 & 16 \\
\hline Yellow corn & 28 & 28 & 28 & 28 & 28 & 28 & 28 \\
\hline Soybean meal (40\%) & 40 & 40 & 40 & 40 & 40 & 40 & 40 \\
\hline Wheat bran & 10.5 & 10 & 9.5 & 9 & 10 & 9.5 & 9 \\
\hline Soybean oil & 2.5 & 2.5 & 2.5 & 2.5 & 2.5 & 2.5 & 2.5 \\
\hline Vit. \&Min. mixture ${ }^{1}$ & 3.0 & 3.0 & 3.0 & 3.0 & 3.0 & 3.0 & 3.0 \\
\hline Oxalic+ malic acid blend $(1: 1)$ & 0 & 0.5 & 1.0 & 1.5 & 0 & 0 & 0 \\
\hline $\mathrm{Ca}$ lactate $+\mathrm{Na}$ acetate blend $(1: 1)$ & 0 & 0 & 0 & 0 & 0.5 & 1.0 & 1.5 \\
\hline sum & 100 & 100 & 100 & 100 & 100 & 100 & 100 \\
\hline \multicolumn{8}{|c|}{ Chemical analysis ( on dry matter basis) } \\
\hline Dry matter $(\mathrm{Dm}) \%$ & 92.56 & 92.79 & 93 & 93.45 & 93.88 & 92.85 & 94.11 \\
\hline Crude protein $(\mathrm{CP}) \%$ & 30.18 & 30.20 & 30.45 & 30.66 & 30.71 & 30.80 & 30.91 \\
\hline Ether extract(EE) \% & 4.44 & 4.34 & 4.22 & 4.23 & 4.87 & 4.20 & 4.36 \\
\hline Crude fiber $(\mathrm{CF}) \%$ & 9,33 & 9.65 & 9.82 & 10.22 & 10.10 & 10.24 & 10.66 \\
\hline Ash \% & 10.12 & 10.12 & 10.14 & 10.14 & 10.33 & 10.45 & 10.15 \\
\hline $\mathrm{NFE}^{2} \%$ & 45.93 & 45.69 & 45.37 & 44.75 & 43.99 & 44.31 & 43.92 \\
\hline $\mathrm{Me}(\mathrm{Kcal} / \mathrm{Kg} \operatorname{diet})^{3}$ & 2610 & 2611 & 2612 & 2609 & 2607 & 2600 & 2595 \\
\hline $\mathrm{P} / \mathrm{E}$ ratio $^{4}$ & 115.6 & 115.7 & 116.6 & 117.5 & 117.8 & 118.5 & 119.1 \\
\hline \multicolumn{8}{|c|}{ 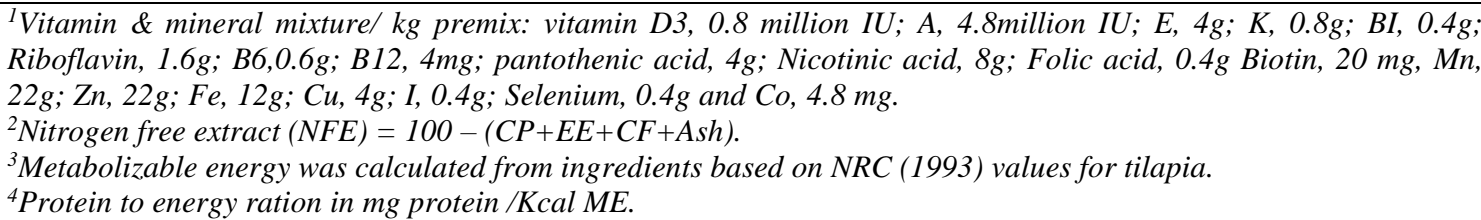 } \\
\hline
\end{tabular}


Table (2). Effect of organic acids and organic salts on growth performance of Nile tilapia $O$. niloticus.

\begin{tabular}{lcccccc}
\hline \multicolumn{1}{c}{ Diets } & \multicolumn{2}{c}{ Body } & weight $(\mathrm{g})$ & \multicolumn{2}{c}{ Body length $(\mathrm{cm})$} & \multicolumn{2}{c}{ WG } & SGR \\
& Initial & Final & Initial & Final BL & (g/fish) & \\
\hline D1 (Control) & BW & BW & BL & & & \\
D2 (malic + oxalic 1:1) $0.5 \%$ & 7.00 & $21.85^{\mathrm{c}}$ & 6.65 & $9.95^{\mathrm{d}}$ & $14.85^{\mathrm{b}}$ & $1.33^{\mathrm{b}}$ \\
D3 (malic + oxalic 1:1) 1.0\% & 7.10 & $24.55^{\mathrm{a}}$ & 6.75 & $10.95^{\mathrm{bc}}$ & $17.45^{\mathrm{a}}$ & $1.38^{\mathrm{a}}$ \\
D4 (malic + oxalic 1:1) 1.5\% & 7.00 & $25.45^{\mathrm{a}}$ & 6.70 & $12.20^{\mathrm{a}}$ & $18.45^{\mathrm{a}}$ & $1.40^{\mathrm{a}}$ \\
D5 (Ca-lactate+Na-acetate 1:1) 0.5\% & 7.15 & $24.40^{\mathrm{a}}$ & 6.90 & $10.50^{\mathrm{cd}}$ & $17.25^{\mathrm{a}}$ & $1.38^{\mathrm{a}}$ \\
D6 (Ca-lactate+Na-acetate 1:1) 1.0\% & 6.90 & $22.85^{\mathrm{b}}$ & 6.70 & $11.70^{\mathrm{ab}}$ & $15.95^{\mathrm{ab}}$ & $1.35^{\mathrm{b}}$ \\
D7 (Ca-lactate+Na-acetate 1:1) 1.5\% & 7.05 & $23.65^{\mathrm{b}}$ & 6.75 & $10.95^{\mathrm{bc}}$ & $16.60^{\mathrm{ab}}$ & $1.37^{\mathrm{ab}}$ \\
Standard error (SE) & 7.20 & $24.55^{\mathrm{a}}$ & 6.85 & $11.00^{\mathrm{bc}}$ & $17.35^{\mathrm{a}}$ & $1.38^{\mathrm{ab}}$ \\
\hline
\end{tabular}

$*$ Means followed by different letters in each column are significantly $(P<0.05)$ different.

Table (3). Effect of organic acids and organic salts on feed intake and feed utilization of Nile tilapia O. niloticus.

\begin{tabular}{lccc}
\hline Diets & $\begin{array}{c}\text { Feed intake } \\
\text { (g/fish) }\end{array}$ & $\begin{array}{c}\text { Feed conversion ratio } \\
(\text { FCR })\end{array}$ & $\begin{array}{c}\text { Protein efficeny ratio } \\
(\text { PER) }\end{array}$ \\
\hline D1 (Control) & $31.35^{\mathrm{b}}$ & $2.11^{\mathrm{a}}$ & $1.85^{\mathrm{d}}$ \\
D2 (malic + oxalic 1:1) $0.5 \%$ & $32.25^{\mathrm{ab}}$ & $1.85^{\mathrm{cd}}$ & $1.81^{\mathrm{ab}}$ \\
D3 (malic + oxalic 1:1) $1.0 \%$ & $33.08^{\mathrm{a}}$ & $1.79^{\mathrm{d}}$ & $1.87^{\mathrm{a}}$ \\
D4 (malic + oxalic 1:1) $1.5 \%$ & $32.43^{\mathrm{ab}}$ & $1.88^{\mathrm{cb}}$ & $1.78^{\mathrm{bc}}$ \\
D5 (Ca-lactate+Na-acetate 1:1) $0.5 \%$ & $31.26^{\mathrm{b}}$ & $1.96^{\mathrm{b}}$ & $1.70^{\mathrm{c}}$ \\
D6 (Ca-lactate+Na-acetate 1:1) $1.0 \%$ & $32.01^{\mathrm{ab}}$ & $1.93^{\mathrm{cb}}$ & $1.73^{\mathrm{bc}}$ \\
D7 (Ca-lactate+Na-acetate 1:1) $1.5 \%$ & $32.54^{\mathrm{ab}}$ & $1.88^{\mathrm{cb}}$ & $1.78^{\mathrm{bc}}$ \\
Standard error (SE) & 0.295 & 0.001 & 0.001 \\
\hline
\end{tabular}

$*$ Means followed by different letters in each column are significantly $(P<0.05)$ different.

Table (4). Effect of organic acids and organic salts on blood of Nile tilapia $O$. niloticus.

\begin{tabular}{lcccccc}
\hline Diets & $\begin{array}{c}\mathrm{Hb} \\
\mathrm{g} / \mathrm{dl}\end{array}$ & $\begin{array}{c}\text { Ht or } \\
(\mathrm{PCV} \%)\end{array}$ & $\begin{array}{c}\text { Total } \\
\text { protein } \\
\mathrm{g} / \mathrm{dl}\end{array}$ & $\begin{array}{r}\text { Total } \\
\text { lipids } \\
\mathrm{g} / \mathrm{dl}\end{array}$ & $\begin{array}{c}\text { ALT } \\
\mu / \mathrm{ml}\end{array}$ & $\begin{array}{r}\text { AST } \\
\mathrm{u} / \mathrm{ml}\end{array}$ \\
\hline D1 (Control) & $8.00^{\mathrm{c}}$ & $29.50^{\mathrm{a}}$ & $5.45^{\mathrm{bc}}$ & $117.5^{\mathrm{a}}$ & 11.50 & $14.5^{\mathrm{ab}}$ \\
D2 (malic + oxalic 1:1) $0.5 \%$ & $8.35^{\mathrm{abc}}$ & $26.50^{\mathrm{ab}}$ & $5.50^{\mathrm{bc}}$ & $103.0^{\mathrm{cb}}$ & 10.50 & $13.0^{\mathrm{b}}$ \\
D3 (malic + oxalic 1:1) 1.0\% & $8.80^{\mathrm{ab}}$ & $29.0^{\mathrm{a}}$ & $5.95^{\mathrm{ab}}$ & $104.5^{\mathrm{cb}}$ & 12.50 & $13.5^{\mathrm{ab}}$ \\
D4 (malic + oxalic 1:1) 1.5\% & $7.95^{\mathrm{c}}$ & $26.0^{\mathrm{ab}}$ & $6.35^{\mathrm{a}}$ & $100.5^{\mathrm{cb}}$ & 12.00 & $14.5^{\mathrm{ab}}$ \\
D5 (Ca-lactate+Na-acetate 1:1) 0.5\% & $8.15^{\mathrm{bc}}$ & $25.5^{\mathrm{ab}}$ & $4.85^{\mathrm{c}}$ & $106.0^{\mathrm{b}}$ & 10.50 & $13.5^{\mathrm{ab}}$ \\
D6 (Ca-lactate+Na-acetate 1:1) 1.0\% & $8.50^{\mathrm{abc}}$ & $24.0^{\mathrm{b}}$ & $5.45^{\mathrm{bc}}$ & $98.0^{\mathrm{c}}$ & 12.00 & $13.5^{\mathrm{ab}}$ \\
D7 (Ca-lactate+Na-acetate 1:1) 1.5\% & $8.00^{\mathrm{c}}$ & $25.5^{\mathrm{ab}}$ & $4.85^{\mathrm{c}}$ & $101.0^{\mathrm{cb}}$ & 13.00 & $16^{\mathrm{a}}$ \\
Standard error (SE) & 0.088 & 2.476 & 0.133 & 7.751 & 2.071 & 0.833 \\
\hline
\end{tabular}

*Means followed by different letters in each column are significantly $(P<0.05)$ different.

Table (5). Effect of organic acids and organic salts blends on proximate chemical analysis of Nile tilapia $O$. niloticus.

\begin{tabular}{lcccc}
\hline \multicolumn{1}{c}{ Diets } & $\begin{array}{c}\text { Dry matter } \\
(\%)\end{array}$ & $\begin{array}{c}\text { Crude } \\
\text { protein }(\%)\end{array}$ & $\begin{array}{c}\text { Crude fat } \\
(\%)\end{array}$ & Ash $(\%)$ \\
\hline Diet 1 (Control) & $27.15^{\mathrm{a}}$ & $68.00^{\mathrm{b}}$ & $14.00^{\mathrm{a}}$ & $14.60^{\mathrm{ab}}$ \\
Diet 2 (malic + oxalic 1:1) $0.5 \%$ & $26.30^{\mathrm{c}}$ & $68.15^{\mathrm{b}}$ & $13.25^{\mathrm{ab}}$ & $14.90^{\mathrm{a}}$ \\
Diet 3 (malic + oxalic 1:1) 1.0\% & $26.80^{\mathrm{b}}$ & $68.85^{\mathrm{b}}$ & $13.15^{\mathrm{ab}}$ & $14.75^{\mathrm{ab}}$ \\
Diet 4 (malic + oxalic 1:1) 1.5\% & $27.05^{\mathrm{ab}}$ & $68.80^{\mathrm{b}}$ & $13.00^{\mathrm{ab}}$ & $14.90^{\mathrm{a}}$ \\
Diet 5 (Ca-lactate+Na-acetate 1:1) 0.5\% & $26.80^{\mathrm{b}}$ & $69.60^{\mathrm{a}}$ & $12.85^{\mathrm{ab}}$ & $15.10^{\mathrm{a}}$ \\
Diet 6 (Ca-lactate+Na-acetate 1:1) 1.0\% & $26.85^{\mathrm{ab}}$ & $69.40^{\mathrm{a}}$ & $13.10^{\mathrm{ab}}$ & $13.70^{\mathrm{c}}$ \\
Diet 7 (Ca-lactate+Na-acetate 1:1) 1.5\% & $26.95^{\mathrm{ab}}$ & $68.80^{\mathrm{b}}$ & $13.35^{\mathrm{ab}}$ & $14.05^{\mathrm{bc}}$ \\
Standard error (SE) & 0.016 & 0.106 & 0.192 & 0.079 \\
\hline
\end{tabular}

*Means followed by different letters in each column are significantly $(P<0.05)$ different. 


\title{
Agouz et al
}

تأثير خلطات بعض الأحماض العضوية وخلطات بعض أملاح الأحماض العضوية على النمو والإستفادة من الغذاء لأسماك البلطى النيلى

\author{
حسام محمود عجوز 1 ومجدى عبدالحميد سلطان 2 و رشا نادى مشرف2

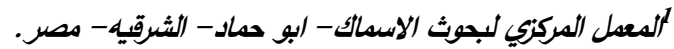

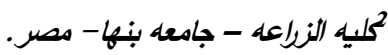

وأجريت هذه لار اسة لمعرفة تأثير إضافة مستويات متز ايدة (1:5، 1.5، 1.5، 1.5\%) من خليط حمضين عضويين هما حمض الماليك

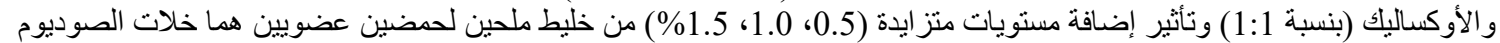

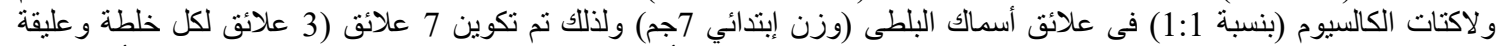
الكتنرول وكل معاملة تشمل على 2 حوض عالى 15 سمكة/حوض). وتم تغذية الأسماك على العلائق السبعة لكدة 90 يوم وكان من أهم النتائج

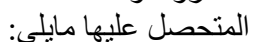

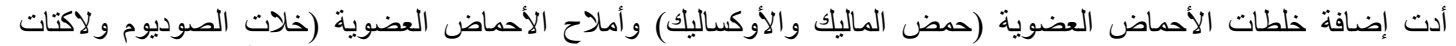

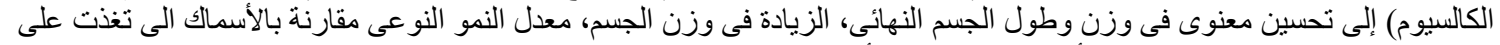

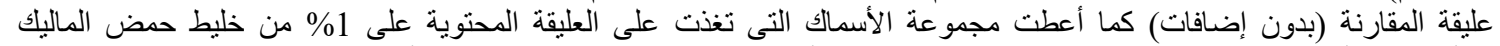

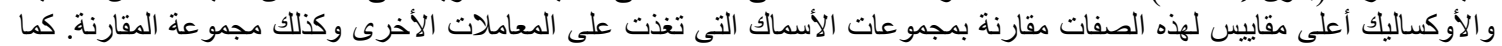

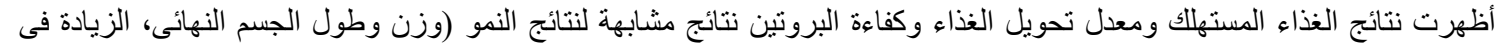

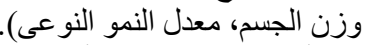

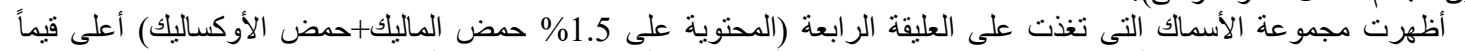

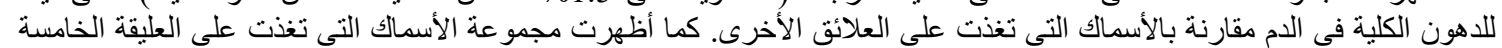

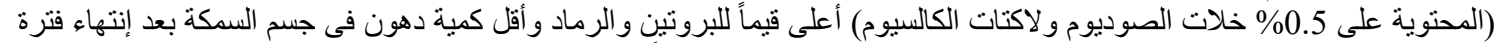

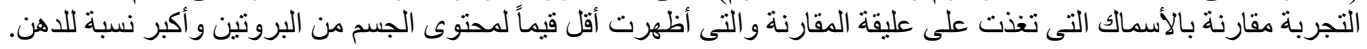

